\title{
Hospital Infection Rates in a Neurology Intensive Care Unit in a One- year Period: Pathogenic and Clinical Evaluation
} Nöroloji Yoğun Bakım Ünitesinde Bir Yıllık Hastane Enfeksiyonu Oranları: Patojenik ve Klinik Değerlendirme

\author{
Fettah Eren¹, Gözde Öngün², Onur Ural³, Şerefnur Öztürk ${ }^{2}$ \\ ${ }^{1}$ Health Sciences University, Konya Training and Research Hospital, Department of Neurology, Konya, Turkey \\ 2Selcuk University Faculty of Medicine, Department of Neurology, Konya, Turkey \\ ${ }^{3}$ Selcuk University Faculty of Medicine, Department of Infectious Diseases and Clinical Microbiology, Konya, Turkey
}

\begin{abstract}
Objective: Nosocomial infections (NI) are serious threats for patients, especially those treated in intensive care units (ICU), which have high risk. Therefore, determining the infectious agents in this area and treating the infections are crucial for both the prognosis of primary disease and the time of stay in hospital. In this study, we aimed to perform an active infection surveillance in the neurological ICU (NICU).

Materials and Methods: Two hundred ninety-one patients who stayed in NICU over a twelve-month period were included in the study. Data obtained by infection control committee of our faculty according to "Centres for Disease Control and Prevention" diagnostic criteria were used for the diagnosis of NI. Isolated microorganisms and their systemic involvement were examined.

Results: The infections in NICU constituted 6.39\% of all NI in the hospital. These were skin and soft tissue infections (3.13\%), bloodstream infections (9.38\%), pneumonia not associated with mechanical ventilator (9.38\%), pneumonia associated with mechanical ventilator (6.25\%), and urinary tract infections (UTI) $(71.88 \%)$. Fourteen different microorganisms were determined in the unit over the twelve months.

Conclusion: Caution is advised regarding urinary catheter insertion and care because catheters are the most common cause of infection, UTI, in the ICU. Also, diagnosis of NI and determining the antibiotic sensitivity of the causal microorganisms are very important for the determination of empiric treatment and reducing mortality and morbidity.
\end{abstract}

Keywords: Nosocomial infection, neurological intensive care unit, surveillance

$\ddot{\mathbf{O} z}$

Amaç: Hastane enfeksiyonları (HE) özellikle yoğun bakım üniteleri (YBÜ) gibi yüksek riskli alanlarda yatan hasta gruplarında ciddi tehdit oluşturmaktadır. Bu alanlardaki enfeksiyon etkenlerinin tanınması ve bu enfeksiyonların tedavisi hem primer hastalığın prognozu hem de hastanede kalış süresi üzerinde etkilidir. Bu çalı̧̧mada nöroloji YBÜ'de (NYBÜ) aktif enfeksiyon surveyans değerlendirmesi yapmayı planladık.

Gereç ve Yöntem: NYBÜ'de on iki aylık sürede 291 hasta çalışmaya dahil edilmiştir. Fakültemiz enfeksiyon kontrol komitesi tarafından tutulan kayıtlar "Hastalık Kontrol ve Önleme Merkezi" (Centers for Disease Control and Prevention) tanı kriterlerine göre incelenmiş ve HE tanısı konulmuştur. İzole edilen mikroorganizmalar ve sistemik tutulumları incelenmiştir.

Bulgular: NYBÜ’deki enfeksiyonlar tüm HE’lerin \%6,39'unu oluşturmaktadır. Bunlar; deri ve yumuşak doku enfeksiyonları (\%3,13), kan dolaşımı enfeksiyonları $(\% 9,38)$, mekanik ventilatörden bağımsız pnömoniler $(\% 9,38)$, ventilatör ile ilişkili pnömoniler $(\% 6,25)$ ve üriner sistem enfeksiyonlarıdır (ÜSE) (\%71,88). Bu ünitede on iki ayda on dört farklı mikroorganizma tespit edilmiştir.

Address for Correspondence/Yazısma Adresi: Fettah Eren MD, Konya Training and Research Hospital, Department of Neurology, Konya, Turkey Phone: +90 5058604146 E-mail: dreren42@hotmail.com ORCID ID: orcid.org/0000-0001-6834-0827

Received/Geliş Tarihi: 03.04.2017 Accepted/Kabul Tarihi: 18.08.2017

${ }^{\circ}$ Copyright 2017 by Turkish Neurological Society

Turkish Journal of Neurology published by Galenos Publishing House. 


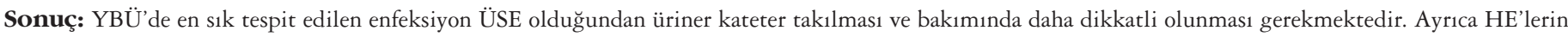

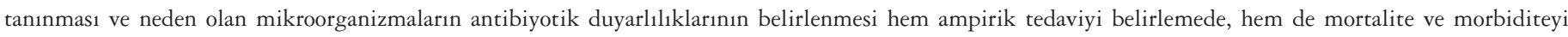
azaltmada oldukça önemlidir.

Anahtar Kelimeler: Hastane enfeksiyonları, nöroloji yoğun bakım ünitesi, surveyans

\section{Introduction}

Infections that are not in the incubation period at admission to hospital and occur 48-72 hours after admission or 10 days after discharge or 30-90 days during the postop period are known as nosocomial infections (NI) (1). Despite all sterilization and disinfection measures, NI is still one of the most important health problems. NI causes extended hospitalization, increases cost, worsens the prognosis of primary disease, and increases morbidity and mortality.

Patients hospitalized in intensive care units (ICU) stay longer in hospital, receive prophylactic broad spectrum antibiotics, and are exposed to more interventional procedures. Therefore, patients staying in ICUs have more infections, which are frequently more resistant $(2,3)$. NI is seen in $5-10 \%$ of hospitalized patients, and this increases up to $20-25 \%$ in the ICU (4). Newborns in whom immune resistance has not yet developed, older patients, immunosuppressed patients, patients being followed up after trauma, patients with a history of malignancy, patients with malnutrition, and those with burns affecting a large surface area are more exposed to NI. Urinary tract infections (UTI), catheter infections, ventilator-associated infections, and infections in surgical wounds are the most commonly seen infections in ICUs $(4,5,6)$.

Third-generation cephalosporins, carbapenem and quinolones are the most commonly used antibiotics in hospitalized patients. Resistance against those antibiotics causes severe complications in critically ill patients with local or systemic infection. Frequent and inappropriate antibiotic use causes resistant NIs. Vancomycin-resistant enterococcus, extended-spectrum betalactamase - producing Escherichia coli, and methicillin-resistant Staphylococcus aureus develop as a result of antibiotic resistance (7). Stay in hospital is increased and prognosis of primary disease worsens because of resistant infections. Therefore, frequently seen microorganisms that cause infections should be determined and appropriate antibiotics should be used at effective doses and for an appropriate duration. Surveillance studies provide detection of frequently seen microorganisms that cause infections and planning of appropriate and successful treatment. Also, detection of frequently seen microorganisms that cause infections is essential for successful planning of empiric treatment. We aimed to determine the epidemiologic features and transmission routes of infections in our neurology ICU (NICU).

\section{Materials and Methods}

Our tertiary NICU in Selçuk University Medical Faculty Hospital, has 7 beds. Three hundred ten patients were hospitalized in the NICU in 2014, 291 of whom were included in the study. Data from infectious diseases nurses, consulting infectious diseases specialists, and responsible neurologists' medical records and visits between January $1^{\text {st }}$ and December $31^{\text {st }}$, 2014, were used in the study.

Patients included in the study were aged over 17 years. Patients who died or were discharged from the NICU within 48 hours of admission were excluded. The criteria of the "Centers of Disease Control and Prevention" were used for the diagnosis of NI (8). When body temperature rose above $38{ }^{\circ} \mathrm{C}$, samples for blood, urine, and throat swab cultures were taken, and samples were taken if the patient had a catheter, phlegm, tracheal aspirate, bronchoalveolar lavage, and wounds. Samples for cultures were taken from the tips of central catheters that were removed. Patients' clinic course and physical examination were evaluated with culture samples. In line with these investigations, hematologic, biochemical and radiologic tests were performed. For infection rate, the following formula was used=Number of infections detected in NICU/number of patients hospitalized in NICU $\times 100$. For the infection ratio, the following formula was used $=$ Number of infections detected in NICU/total number of infections in the hospital x 100. Other formulas used were as follows: for ventilator-associated pneumonia (VAP) rate $=$ Number of $\mathrm{VAP} /$ number of days on ventilator $\mathrm{x} 100$, for the catheter-associated urinary tract infection $(\mathrm{CA}-\mathrm{UTI})$ rate=Number of CA-UTI/number of days with urinary catheter (UC) $\mathrm{x} 100$, and for the central venous catheter-associated bloodstream infection $(\mathrm{CVC}-\mathrm{ABI})$ rate $=$ Number of CVC-ABI/number of days with CVC x 100.

Samples taken were embedded in eosin methylene blue agar and blood agar. Samples from phlegm, wounds, and catheters were investigated for the existence of leukocytes using Gram staining. Blood culture bottles were monitored daily for growth. For growing microorganisms, colony and Gram staining features were defined. Gram (+) microorganisms were classified according to growth in coagulase, catalase, pyrrolidonyl arylamidase, esculin hydrolysis, and $6.5 \%$ sodium chloride. Gram (-) microorganisms were classified using the oxidase test, motility test medium, indole medium, and Christensen urea agar.

The study were approved by the Selcuk University of Local Ethics Committee (Protocol number: 2017/02). We did not receive consent form because this study is a retrospective study.

\section{Statistical Analysis}

For statistical evaluation of the data, SPSS 16 was used. With this pocket program, descriptive statistical evaluations were performed.

\section{Results}

Patients hospitalized in the NICU during a one-year period were retrospectively evaluated. A total of 291 patients were included in the study. Of these patients, $156(53.6 \%)$ were females and $135(46.3 \%)$ were males. The mean age of the patients was 71.36 years. One hundred seventeen $(40.2 \%)$ patients with ischemic stroke, 35 (12\%) with hemorrhagic stroke, 6 (2\%) with 
subarachnoid hemorrhage (SAH), $20(6.8 \%)$ with encephalitis, $27(9.2 \%)$ with epilepsy, $16(5.5 \%)$ with myelitis, $13(4.4 \%)$ with Parkinson's disease, $19(6.5 \%)$ with dementia, $8(2.7 \%)$ with motor neuron disease, and $30(10.3 \%)$ with Guillain Barre syndrome (GBS) were followed up. In their medical history, 140 (48.1\%) had diabetes mellitus, $110(37.8 \%)$ had hypertension, 56 $(17.1 \%)$ had congestive heart failure, and $18(6.1 \%)$ had chronic renal failure. NIs were detected in 45 patients, $24(53 \%)$ of whom were females and $21(47 \%)$ were males. Twenty (44\%) of these patients had ischemic stroke, $12(27 \%)$ had hemorrhagic stroke, 5 (11\%) had GBS, 3 (6.6\%) had epilepsy, 1 (2.2\%) had Parkinson's disease, and $1(2.2 \%)$ had SAH. The NI rate in the NICU was $15.4 \%$ (Table 1, 2).

In our NICU, the number of ventilator days and rate of ventilator use were 594 and $30 \%$, respectively, and the rate of VAP was $13.4 \%$; the number of UC days and rate of UC use were 1778 and $92 \%$, respectively, and the rate of UTI was $10.6 \%$; the number of CVC days and rate of CVC use were 395 and 15\%, respectively, and the rate of CVCAS was $3.39 \%$. These data are summarized in Table 3.

Fourteen microorganisms that cause NI were detected. Of all infections, 3.2\% were skin and soft tissue infections caused by Staphylococcus aureus $(50 \%)$ and Acinetobacter baumannii (50\%); 9.38\% were bloodstream infections caused by coagulase (-) Stapbylococcus; $9.38 \%$ were pneumonia not associated with ventilator caused by Staphylococcus aureus (33.3\%) with specific laboratory findings and Burkholderia cepacia (33.3\%) and Klebsiella pneumoniae $(33.3 \%)$ without specific laboratory findings.

The number of infections detected in the NICU in one year constituted $6.39 \%$ of all infections detected in the hospital. The

\begin{tabular}{|lc|}
\hline Table 1. Demographic features of patients in neurology \\
intensive care unit in one-year period \\
Sex \\
Female & $156(53.6 \%)$ \\
Male & $135(46.3 \%)$ \\
Diagnosis & 291 \\
Ischemic stroke & $117(40.2 \%)$ \\
Hemorrhagic stroke & $35(12 \%)$ \\
Subarachnoid hemorrhage & $6(2 \%)$ \\
Guillain Barre syndrome & $30(10.3 \%)$ \\
Epilepsy & $27(9.2 \%)$ \\
Encephalitis & $20(6.8 \%)$ \\
Dementia & $19(6.5 \%)$ \\
Myelitis & $16(5.5 \%)$ \\
Parkinson's disease & $13(4.4 \%)$ \\
Motor neuron disease & $8(2.7 \%)$ \\
Comorbid diseases & 324 \\
Diabetes mellitus & $140(48.1 \%)$ \\
Hypertension & $110(37.8 \%)$ \\
Congestive heart failure & $56(17.1 \%)$ \\
Chronic renal failure & $18(6.1 \%)$ \\
\hline
\end{tabular}

most frequent seen NI was UTI with a rate of $71.88 \%$. Of the UTIs, 95\% were associated with UC and 5\% were not. Just over $30 \%(30.43 \%)$ of UTIs were caused by Escherichia coli, $13.04 \%$ by Klebsiella pneumoniae, $13.04 \%$ by Enterococus faecalis, $8.7 \%$ by Staphylococcus aureus, $4.35 \%$ by Candida glabrata, $4.35 \%$ by Candida spp., $4.35 \%$ by Candida tropicallis, $4.35 \%$ by Citrobacter species $4.35 \%$ by Enterococus faecium, $4.35 \%$ by coagulase (-) Staphylococcus, $4.35 \%$ by Proteus mirabilis, and $4.35 \%$ by Pseudomonas aeruginosa. The rate of mechanical ventilator-associated infections in the NICU was $6.25 \%$ and $50 \%$ were caused by Acinetobacter baumannii and $50 \%$ by Pseudomonas aeruginosa. The regional distribution of those infections and the percentages of the most frequently seen UTIs are summarized in Table 4, 5. Also, the most frequent infections in other ICUs of the hospital were evaluated. The rates of infections in anesthesiology, general medicine and general surgery ICUs were $60 \%, 72 \%$, and $62 \%$ for UTIs; $12.14 \%, 7.2 \%$, and $4 \%$ for ventilator-associated infections; and $8.2 \%, 3.8 \%$, and $5 \%$ for CVC-associated infections, respectively.

\section{Discussion}

ICU's are multidisciplinary study units with advanced technological hardware and professional equipment. Patients

\begin{tabular}{lc|}
\hline $\begin{array}{l}\text { Table 2. Demographic features of patients with nosocomial } \\
\text { infections in neurology intensive care unit in one-year } \\
\text { period }\end{array}$ \\
Total number of patients \\
Sex \\
$\quad$ Female \\
Male & $24(53 \%)$ \\
Diagnosis & $21(47 \%)$ \\
Ischemic stroke & \\
Hemorrhagic stroke & $20(44 \%)$ \\
Guillain Barre syndrome & $12(27 \%)$ \\
Epilepsy & $5(11 \%)$ \\
Dementia & $3(6.6 \%)$ \\
Parkinson's disease & $3(6.6 \%)$ \\
Subarachnoid hemorrhage & $1(2.2 \%)$ \\
\hline
\end{tabular}

Table 3. Use of mechanical ventilators, urinary catheters, and central venous catheters, and associated infection rates in the neurology intensive care unit in one-year period

\begin{tabular}{|lcc|}
\hline Mechanical ventilator use & Days & $\%$ \\
Rate of ventilator-associated pneumonia & 594 & 30 \\
Urinary catheter use & - & 13.4 \\
$\begin{array}{l}\text { Rate of catheter-associated urinary tract } \\
\text { infection }\end{array}$ & - & 1778 \\
$\begin{array}{l}\text { Central venous catheter use } \\
\begin{array}{l}\text { Rate of central venous catheter-associated } \\
\text { septicemia }\end{array}\end{array}$ & 295 & 15 \\
\hline
\end{tabular}


hospitalized in ICUs are complex patients with severe metabolic disturbances, changes in consciousness, and comorbid diseases. Having low immune resistance and multiple organ dysfunctions facilitate colonization and infection. Also, long-period induration of central or peripheral catheters, endotracheal tubes, and UCs increase susceptibility to infections $(9,10)$. Our finding of high variability of infectious agents and high infection rates in patients with catheters also supports this argument.

In a study, the incidence of NI was found as $18.3 \%$ in the anesthesiology and reanimation ICU (ARICU), 5.6\% in the chest diseases ICU, and $5.3 \%$ in the pediatric ICU (11). In another study, infection rates in all ICUs were found between 1.6-47.4\% with the

Table 4. Regional distribution of nosocomial infections in the neurology intensive care unit in one-year period

Skin and soft tissue infection

3.12

Bloodstream infection 9.38

Laboratory-proven bloodstream infections 66.67

Central venous catheter-associated bloodstream 33.33 infection

Pneumonia

Pneumonia without specific laboratory findings 66.67

Pneumonia with specific laboratory findings 33.33

Urinary tract infection

71.88

Urinary tract infection associated with urinary catheter 95

Urinary tract infection not associated with urinary catheter

Lung infection associated with mechanic ventilator

6.25

Table 5. Microorganisms and their distribution that caused nosocomial urinary tract infections in the neurology intensive care unit in one-year period

\begin{tabular}{|lc|} 
& $\%$ \\
Associated with urinary catheter & 95 \\
Candida glabrata & 4.35 \\
Candida spp. & 4.35 \\
Candida tropicalis & 4.35 \\
Citrobacter & 4.35 \\
Enterococcus faecalis & 13.04 \\
Enterococcus faecium & 4.35 \\
Escherichia coli & 30.43 \\
Klebsiella pneumoniae & 13.04 \\
Coagulase-negative Staphylococcus & 4.35 \\
Proteus mirabilis & 4.35 \\
Pseudomonas aeruginosa & 4.35 \\
Staphylococcus aureus & 8.7 \\
Not associated with urinary catheter & 5 \\
Escherichia coli & 100 \\
\hline
\end{tabular}

highest rate of $44.6 \%$ in the ARICU (12). Infection rates were found as $18.5 \%$ and $24.2 \%$ in the NICU in two studies $(13,14)$. Our infection rate was $15.4 \%$ in our NICU. Our infection rate was lower than the literature data from previous years. This decrease in the NI rate could be related with the increase in technical facilities, having more groups of antibiotics, and the increased awareness of health care workers about infection and hand washing.

In our NICU, the rate of patients with ventilators was $30 \%$, the rate of VAP was $13.4 \%$, the rate of UC use was $92 \%$, the rate of UTI was $10.6 \%$, the rate of CVC use was $15 \%$, and the rate of CVCAS was $3.39 \%$. The data from 19 university hospitals were evaluated by the National NI Surveillance Network in 2014. The rate of patients with ventilators and rates of VAP, UC use, UTI, CVC use, and CVCAS were 38\%, $12.7 \%, 95 \%, 6.3 \%$, $27 \%$, and $6.7 \%$, respectively (15). Our NICU was compared with other NICUs according to these data. The use of CVC and rate of CVC-associated diseases were found statistically lower compared with other NICUs. UTI and VAP rates were found statistically higher compared with other NICUs. The NICUs in all public, private, and university hospitals in Turkey were evaluated in the same period and it was found that rate of patients with ventilators was $30 \%$, the rate of VAP was $10.3 \%$, the rate of UC use was $97 \%$, the rate of UTI was $5.2 \%$, the rate of CVC use was $26 \%$, and the rate of CVCAS was $4.7 \%$ (15). When all NICUs were compared with NICUs in university hospitals, the rate of patients with ventilators and rates of VAP were found higher in university hospitals. It was found that the use of UCs and CVCs was similar in all NICUs but UTI and CVCAS rates were higher in NICUs in university hospitals. Longer hospitalization of more complicated patients with lower immune resistance in NICUs in university hospitals could be the reason for these results. Also, all kinds of interventions increase infection rates.

Multiple organ failure and systemic involvement can be caused by infections in patients hospitalized in the ICU. In particular, UTIs, pulmonary infections, and CVCAS are more frequently seen. NI was detected in 114 of 314 patients hospitalized in the ICU in a study. The most frequently seen infection was UTI and it was mostly caused by Escherichia coli (29.8\%), followed by Klebsiella pneumoniae $(16,17)$. The high rate of UTI was thought to be caused by frequent UC use in ICUs $(18,19)$. In our study, UTI was also the most frequently seen infection. Moreover, the greatest variation in microorganisms was observed in UTIs. This high rate could be due to UC use in $92 \%$ of patients. Also, $95 \%$ of the UTIs were associated with UC use in our study, which also supports this argument. The microorganisms causing UTIs were Escherichia coli $(30.43 \%)$, Klebsiella pneumoniae (13.04\%), Enterococcus faecalis (13.04\%), and Staphylococcus aureus (8.7\%), which were in line with the literature.

Studies searching pulmonary infections in ICUs show that $\mathrm{NI}$ is seen in most patients who are intubated, and in the vast majority of patients who are linked to mechanical ventilators (20,21,22,23). Pulmonary infection is the second most frequently seen infection in the NICU as in other ICUs with a rate of $31.4 \%$ (24). Inappropriate or appropriate but delayed use of antibiotics are related with increased mortality in patients with pulmonary infection in ICUs (25). Therefore, it is important to detect the microorganisms that cause pulmonary infections. The most frequently seen microorganisms that cause pulmonary 
infections are Acinetobacter baumannii, Pseudomonas aeruginosa, and Staphylococcus aureus (26). In our study, the most frequently isolated microorganisms that cause mechanical ventilatorassociated pulmonary infections were Acinetobacter baumannii and Pseudomonas aeruginosa. Burkholderia cepacia, Klebsiella pneumoniae, Staphylococcus aureus were the microorganisms that caused a rare-form pulmonary infection, which is not associated with mechanical ventilation. Empirical antibiotic treatment should be adjusted against these microorganisms with an appropriate dose and delivery time.

Bloodstream infections are mostly related with CVC use and causes severe sepsis. These infections can cause severe morbidity and mortality and must be detected rapidly. The most frequently seen microorganisms that cause bloodstream infections are Staphylococcus aureus and coagulase (-) Staphylococcus (27). Also, skin and soft tissue infections are seen in patients hospitalized in ICUs for long periods; these disrupt healing of bed sores and worsen prognosis. Staphylococcus aureus is detected often in skin and soft tissue infections (28). In our study, we found that coagulase (-) Staphylococcus was the most frequent cause of bloodstream infections and Acinetobacter baumannii and Stapbylococcus aureus were the most frequent causes of skin and soft tissue infections.

\section{Conclusion}

Patients hospitalized in ICUs have reduced immune resistance and many systemic diseases, which make them vulnerable to NIs. NIs increase morbidity, mortality, and hospital stay. Therefore, attention should be given to infection control measures to prevent the transmission and spread of these microorganisms. Infection rates and measures should be continuously monitored and compared with other centers. In this way, we should have effective infection control. Recognizing NIs, and detecting the causing microorganisms and their antibiotic sensitivities are important in determining empiric treatment and improving morbidity and mortality. The most frequently seen infection in the ICU is UTI, and greater caution with UC application and care is recommended. Attention should be given to measures such as hand washing, wearing gloves, and isolation in every intervention performed to patients.

\section{Ethics}

Ethics Committee Approval: The study were approved by the Selcuk University of Local Ethics Committee (Protocol number: 2017/02).

Informed Consent: We did not receive consent form because this study is a retrospective study.

Peer-review: Externally peer-reviewed.

\section{Authorship Contributions}

Surgical and Medical Practices: F.E., G.Ö., Concept: Ş.Ö., O.U., Design: F.E., Ş.Ö., O.U., Data Collection or Processing: F.E., G.Ö., Analysis or Interpretation: F.E., Ş.Ö., Literature Search: F.E., G.Ö., Writing: F.E.

Conflict of Interest: No conflict of interest was declared by the authors.

Financial Disclosure: The authors declared that this study received no financial support.

\section{References}

1. Çevik MA, Yılmaz GR, Erdinç FŞ, Üçler S, Tülek N. Nöroloji yoğun bakım ünitesinde mortalite ile ilişkili faktörler ve nozokomiyal infeksiyonla mortalitenin ilişkisi. Yoğun Bakım Dergisi 2001;1:47-55.

2. Ok G, Gazi H, Tok D, Erbüyün K. Celal Bayar Üniversitesi Anestezi Yoğun Bakım Ünitesi'nde hastane infeksiyonlarının sürveyansı. Yoğun Bakım Dergisi 2007;7:452-457.

3. Yılmaz N, Köse Ş, Ağuş N, Ece G, Akkoçlu G, Kıraklı C. Yoğun bakım ünitesinde yatan hastaların kan kültürlerinde üreyen mikroorganizmalar, antibiyotik duyaklılıkları ve nozokomiyal bakteriyemi etkenleri. ANKEM Dergisi 2010;24:12-19.

4. Kappstein I, Daschner FD. Nosocomial infections in intensive care units. Current Opinion Infectious Diseases 1990;3:509-512.

5. Larsen AR. Nosocomial infections. In: Hoeprich PD, Jordan MC, (eds). Infectious Disease 4th ed. Phledelpiha: JB Lippincott Company, 1989:35-40.

6. Gürdoğan K, Arslan H, Nazlıer S. Ventilatör ilişkili pnömoniler. Klimik Dergisi 1999;12:58-59.

7. Yalçın AN. Yoğun bakım ünitesinde antibiyotik kullanımı ve direnç sorununa genel bakış. ANKEM Dergisi 2009;23(Özel Sayı):136-142.

8. Girou E, Stephan F, Novara A, Safar M, Fagon JY. Risk factors and outcome of nosocomial infections: results of a matched case-control study of ICU patients. Am J Respir Crit Care Med 1998;157:1151-1158.

9. Brawley RL, Weber DJ, Samsa GP, Rutala WA. Multiple nosocomial infections: An incidence study. Am J Epidemiol 1989;130:769-780.

10. Spencer RC. Epidemiology of infection in ICU's. Intensive Care Med 1994;20(Suppl 4):2-6.

11. Karahocagil MK, Yaman G, Göktaş U, Sünnetçioğlu M, Çıkman A, Bilici A, Yapıcı K, Baran Aİ, Binici İ, Akdeniz H. Hastane enfeksiyon etkenlerinin ve direnç profillerinin belirlenmesi. Van Tip Derg 2011;18:27-32.

12. İnan D, Saba R, Keskin S, Öğ̈ünç D, Çiftci C, Günseren F, Mamıkoğlu, Gültekin M. Akdeniz Üniversitesi Hastanesi yoğun bakım ünitelerinde hastane enfeksiyonları. Yoğun Bakım Dergisi 2002;2:129-135.

13. Zolldann D, Poetter C, Hilker R, Neveling M, Waitschies B, Klein W, Nolden-Koch M, Block F, Wenchel HM, Lemmen SW. Periodic surveillance of nosocomial infections in two neurology intensive care units. A valuable tool for quality management in intensive care. Anaesthesist 2003;52:690696.

14. Dettenkofer M, Ebner W, Els T, Babikir R, Lucking C, Pelz K, Rüden H, Daschner F. Surveillance of nosocomial infections in a neurology intensive care unit. J Neurol 2001;248:959-964.

15. Ulusal hastane enfeksiyonları sürveyans ağı (UHESA) raporu özet veri, 2014. Erişim adresi: http://www.saglik.gov.tr/TR/dosya/1-97084/h/2014-ulusalozet-rapor-1.pdf

16. Warren JW. Catheter associated urinary tract infections. Int J Antimicrob Agents 2001;17:299-303.

17. Heckmann JG, Kraus J, Niedermeier W, Erbguth F, Druschky A, Schoerner C, Neundörfer B. Nosocomial pneumonias in a neurology intensive care unit. Dtsch Med Wochenschr 1996;124:919-924.

18. Laborde G, Grosskopf U, Schmieder K, Harders A, Klimek L, Hardenac M, Gilsbach JM. Nosocomial infections in a neurosurgical intensive care unit. Anaesthesist 1993;42:724-731.

19. National Nosocomial Infections Surveillance (NNIS) System Report, data summary from January 1992 through June 2004, issued October 2004. Am J Infect Control 2004;32:470-485.

20. Craven DE, Kunches LM, Lichtenberg DA, Kollisch NR, Barry MA, Heeren TC, McCabe WR. Nosocomial infection and fatality in medical and surgical intensive care unit patients. Arch Intern Med 1988;148:1161-1168.

21. Ponce DE Leon-Rosales SP, Molinar-Ramos F, Dominguez-Cherit G, RangelFrausto MS, Vazquez-Ramos VG. Prevalance of infections in intensive care units in Mexico: A multicenter study. Crit Care Med 2000;28:1316-1321.

22. Legras A, Malvy D, Quinioux AI, Villers D, Bouachour G, Robert R, Thomas R. Nosocomial infections: Prospective survey of incidence in fi ve intensive care units. Int Care Med 1998;24:1040-1046.

23. Vincent JL, Bihari DJ, Suter PM, Bruining HA, White J, Nicolas-Chanoin MH, Wolff M, Spencer RC, Hemmer M. The prevalence of nosocomial infection in intensive care units in Europe. Results of the European Prevalence 
of Infection in Intensive Care (EPIC) Study. EPIC International Advisory Committee. JAMA 1995;274:639-644.

24. Heckmann JG, Kraus J, Niedermeier W, Erbguth F, Druschky A, Schoerner C, Neundörfer B. Nosocomial pneumonias in a neurology intensive care unit. Dtsch Med Wochenschr 1996;124:919-924.

25. Luna CM, Aruj P, Niederman MS, Garzon J, Violi D, Prignoni A, Rios F, Baquero S, Gando S; Grupo Argentino de Estudio de la Neumonía Asociada al Respirador group. Appropriateness and delay to initiate therapy in ventilator associated pneumoia. Eur Respir J 2006;27:158-164.
26. Sherertz RJ, Ely EW, Westbrook DM, Gledhill KS, Streed SA, Kiger B, Flynn L, Hayes S, Strong S, Cruz J, Bowton DL, Hulgan T, Haponik EF. Education of physicians in training can decrease the risk for vascular catheter infection. Ann Intern Med 2000;132:641-648.

27. Akın A, Esmaoğlu-Çoruh A, Alp E, Canpolat DG. Anestezi yoğun bakım ünitesinde beş yıl içerisinde gelişen nozokomiyal enfeksiyonlar ve antibiyotik direncinin değerlendirilmesi. Erciyes Tip Derg 2011;33:7-16.

28. Büke C, Sipahi O, Taşbakan M, Yamazhan T, Arda B, Özinal MA, Akçiçek $\mathrm{M}$, Ulusoy $\mathrm{S}$. İç hastalıkları yoğun bakımda gelişen enfeksiyonların değerlendirilmesi. İnfeksiyon Dergisi 2005;19:67-73. 